\title{
Teaching to the 'other': Comparative perspectives of Netherlander and Turkish teachers' attitudes on gender identity
}

\section{Ensinando "o outro": Perspetivas comparativas de atitudes de professores holandeses e turcos sobre a identidade de gênero}

\author{
Nesrin Oruc Erturk ${ }^{*}$
}

\begin{abstract}
This paper reports on the findings of a mixed method comparative study investigating teachers' perceptions of gender identity in Netherlands and Turkey. Data was collected via an online survey from 506 teachers followed by a focus group interview with a small subgroup. An analysis of the results of qualitative data focus on teacher experiences with and attitudes to gender identity, particularly in relation to practices. Findings indicate that despite the culturally diverse background, the participant teachers from both countries seemed to agree on some of the items; however, Turkish teachers were generally more conservative and less tolerant to 'the other'. The presentation will at the end discuss the urgent need, especially in Turkey, for more research that explores how teachers can learn to become a guide to 'the other', and the extent to which this increases the student motivation and success. Teachers in Turkey are not deliberately obstructive, but they lack the knowledge to perform this role of guiding students with a different sexual preference. The first step is providing training for school staff to improve rates of intervention and increasing the number of supportive teachers, as well as other staff available can be the first resulting in a healthier and happier community. It is important to find ways to train teachers with the skills and attitudes that will create more vibrant and diverse schools.
\end{abstract}

Keywords: Teacher perspectives. Gender identity. Inclusion. Netherlands. Turkey.

* Izmir University of Economics. Izmir, Turquia. E-mail: nesrinoruc@yahoo.com. https:// orcid.org/0000-0003-1324-8796. 


\section{RESUMO}

Este documento (estudo, ensaio, tese) relata as conclusões de um estudo misto comparativo que investiga as perceções de professores sobre a identidade de gênero na Holanda e na Turquia. Os dados foram coletados por meio de inquérito online a 506 professores seguido de uma entrevista de grupo, focada num sub grupo. Uma análise dos resultados dos dados qualitativos foca nas experiências e atitudes de professores relacionadas com identidade de gênero, particularmente em relação às suas práticas. Os resultados indicam que, apesar da experiência culturalmente diversa, os professores que participaram de ambos os países parecem concordar em alguns pontos; no entanto, os professores turcos são geralmente mais conservadores e menos tolerantes para com "o outro". O estudo (documento, ensaio) aborda a necesssidade urgente, especialmente na Turquia, de mais pesquisa que explore a forma como os professores podem aprender a se tornar num guia para " 0 outro", e o quanto isto poderá aumentar a motivação e o sucesso do aluno. Os professores na Turquia não são deliberadamente obstrutivos, mas falta-lhes o conhecimento para poder desempenhar o papel de orientar estudantes com uma preferência sexual diferente. O primeiro passo é providenciar formação ao quadro de funcionários da escola para melhorar as taxas de intervenção e aumentar o número de professores assistentes, bem como outros funcionários disponíveis resultarão numa comunidade mais saudável e mais feliz. É importante encontrar como formar professores com as competências e atitudes que criarão escolas mais vivas e com mais diversidade.

Palavras-chave: Perspetivas de professores. Identidade de gênero. Inclusão. Holanda. Turquia.

\section{Introduction}

In contrast to certain parts of the world, in Turkey you would be unlikely to hear a teacher talking to a student or a colleague about their own or students' sexual preferences and/or gender identity. If, by some chance, the topic arose accidentally, both parties would look for ways to change it. The reason why gender identity is rarely addressed in schools in Turkey is the teachers' own fears, prejudices and concerns. Talking about the topic or being heard when making a comment about it may be considered as evidence or a tendency to non-heterosexuality, which could ruin their private and professional reputation. This silence in schools about gender identity is a sign of a taboo shaped over years of living in a closed society. Heteronormativity, defined by Müller 
(2015) as a social construct that unfortunately makes 'the other identities' invisible, and assumes that heterosexual relationships are the norm, is dominant in my country.

In her article, Richard (2015) states that teachers in Canada look for answers to questions such as how to react to a student who confides in that he may be bisexual, or a student asking about coming out. However, it is very rare that a high school student confides in such a way in Turkey. In order to do that there must be a complete trust, but inevitably in an environment where the students have no clues about the teachers' attitude towards the issue, they keep silent, which then exacerbates the problems.

If, in a country where the teachers have implemented a series of community projects and initiatives on sex education to ensure that elementary and high school students learn the basics of sexuality, it is still considered that the country lacks important programs to adequately address heteronormativity in schools (Richard, 2015), then in Turkey, we still have much work to do. Therefore, the aim of this study is twofold: first, to identify Turkish teachers' feelings about gender identity, and second, to compare their attitudes with Netherlander teachers. In this study, teachers' experiences, histories and personal ideas on sexual orientation and gender identity were of interest, and provided a starting point for data analysis.

\section{Why teachers should learn about sexual orientation and gender identity}

It is a fact that implicit and explicit messages in support of heteronormativity dominate schools (Ferfolja, 2007). Therefore, by identifying the teachers' perspectives on gender identity, teachers can assess themselves - what is known and unknown - and increase their awareness on how important it is to have knowledge about the topic, since this is the key decreasing verbal sexual harassment, and even physical abuse at schools.

Sexual and gender minority youth face challenges throughout their lives. Fear about how family and friends may react, as well as fear of bullying, harassment, discrimination and prejudice in school may prevent young people from publicly identifying as a sexual or gender minority (Gorski, Shannon \& Reiter, 2013). Supportive families, schools and communities have a vital role in helping these children adapt to school and succeed in life. Unfortunately, studies reveal that our schools still lack tolerance. According to the results of the GLSEN's 
(Kosciw, Greytak, Bartkiewicz, Boesen \& Palmer, 2012) National School Climate Survey, more than half of students reported hearing homophobic remarks from school personnel, and less than a fifth reported that school personnel frequently intervened when hearing homophobic remarks, or negative comments on gender expression. In addition, 4 out of 10 students often or frequently heard their peers make racist remarks at school. These facts underline the importance of teachers and their perception about the topic. Studies show lower levels of bullying or a reduction in bullying behaviour over time in schools in which students perceive higher levels of support from teachers (Kosciw, Greytak, Palmer \& Boesen, 2014).

Another reason why teachers should learn about sexual orientation and gender identity is that, even though it is well-known that gender identity itself is not a health hazard, if these issues are ignored, the resulting social exclusion will lead to significant health disparities (Müller, 2015). Homophobia and heteronormativity are powerful constructs that have both direct and indirect impacts on the health of youth people. When labelled as a marginalised group, such students experience higher levels of depression, suicide and substance abuse, and are at higher risk of sexually transmitted diseases, including HIV (Müller, 2015), although actual levels will depend on the tolerance level of their community.

A review of the literature stated above resulted in two themes that helped me situate this study: (1) the attitudes of Turkish teachers toward gender identity. What they believe, how they perceive it and how these perceptions affect their practice in the classroom, and (2) what are the differences between teachers from the Netherlands and Turkey, which are culturally dissimilar, in terms of attitudes to gender identity?

\section{Materials and Methods}

\section{Participants}

Participants of this study were 118 male and 368 female (311 Netherlander-195 Turkish) teachers, of a variety of subjects ranging from Physical education to ICT. The participants' location, type of the school, age, teaching experience and other details are given below. 
TABLE 1. PROFILE OF PARTICIPANTS

\begin{tabular}{|c|c|c|c|}
\hline & Netherlands & Turkey & Total \\
\hline \multicolumn{4}{|l|}{ Gender } \\
\hline Female & 216 & 168 & 384 \\
\hline Male & 90 & 27 & 117 \\
\hline \multicolumn{4}{|l|}{ Location } \\
\hline Countryside & 37 & 3 & 40 \\
\hline Village & 26 & 13 & 39 \\
\hline Town or city & 242 & 179 & 421 \\
\hline \multicolumn{4}{|l|}{ Type of School } \\
\hline General education & 263 & 152 & 415 \\
\hline Vocational education & 29 & 23 & 52 \\
\hline Mixed & 6 & 16 & 22 \\
\hline \multicolumn{4}{|l|}{ Age } \\
\hline-30 & 55 & 66 & 121 \\
\hline $30-39$ & 100 & 77 & 177 \\
\hline $40-49$ & 78 & 41 & 119 \\
\hline $50+$ & 67 & 7 & 74 \\
\hline \multicolumn{4}{|l|}{ Years of Experience } \\
\hline $1-5$ & 95 & 61 & 156 \\
\hline $6-10$ & 68 & 39 & 107 \\
\hline $11-20$ & 76 & 63 & 139 \\
\hline $20+$ & 58 & 28 & 86 \\
\hline \multicolumn{4}{|c|}{ Number of Teaching Hours } \\
\hline $1-5$ & 5 & 16 & 21 \\
\hline $5-10$ & 19 & 14 & 33 \\
\hline $10-15$ & 40 & 13 & 53 \\
\hline $15-20$ & 71 & 42 & 113 \\
\hline $20+$ & 163 & 105 & 268 \\
\hline \multicolumn{4}{|l|}{ Subject } \\
\hline Economics & 26 & 3 & 29 \\
\hline Math & 74 & 28 & 102 \\
\hline Languages & 93 & 56 & 149 \\
\hline Foreign Languages & 87 & 91 & 178 \\
\hline History & 52 & 12 & 64 \\
\hline Physical Education & 31 & 11 & 42 \\
\hline Biology & 92 & 10 & 102 \\
\hline Physics & 78 & 10 & 88 \\
\hline Chemistry & 78 & 10 & 88 \\
\hline Geography & 35 & 4 & 39 \\
\hline Art education & 26 & 15 & 41 \\
\hline
\end{tabular}




\begin{tabular}{llll} 
(Conclusion) & & & \\
ICT & 17 & 3 & 20 \\
Music & 17 & 11 & 28 \\
Others & 100 & 27 & 127 \\
Sexual Identification & & & \\
Heterosexual & 250 & 136 & 386 \\
Homosexual & 37 & 3 & 40 \\
Asexual & 9 & 17 & 26 \\
Don't know & 1 & 7 & 8 \\
Bisexual & 1 & 2 & 3 \\
Highest level of study & & & \\
PhD & 6 & 19 & 25 \\
MA & 272 & 42 & 314 \\
BA & 9 & 123 & 132 \\
\hline
\end{tabular}

SOURCE: Prepared by the author.

Participants completed a survey on their ideas and perceptions about differences between girls and boys, homosexuality, gender identity, preferences for gender of students, and their relations with, and reactions to, non-heterosexual students and colleagues in school. The final sample consisted of 506 teachers between the ages of 24 and 59 .

\section{Instrument}

The survey had two parts. The first part of the survey elicited demographic data such as: age, length of teaching, type of school, subject, and highest level of study. The second part, the main section, focused on the perceptions of sex (gender issues) and gender identity issues. In total, there were 12 items on the first, and 39 items on the second part of the questionnaire. All the items on the scale were developed together with the Netherlander colleague, using information from the literature and the researchers' own expertise.

In order to identify the extent to which our instrument captured the theoretical construct, namely gender identity, first, a factor analysis was conducted, and three main factors were identified:

a) Gender: consisting of 8 items testing the teachers' understanding of gender issues (concerning cultural behaviour standards based on gender);

b) Gender Identity: consisting of 14 items testing teachers' attitudes on gender identity (focused on inside feelings, and expressions of gender through clothing, behaviour, and personal appearance); 
c) Gender Identity and Teaching: consisting of 17 items on how teachers' opinions are reflected in the classroom and/or how their beliefs affect their teaching.

Kaldi, Govaris \& Filippatou (2018) describe the value of using a Likerttype scale in terms of affording the researcher the freedom to fuse measurement with opinion, quantity and quality; however, they also warn of limitations: issues of participants' honesty (hiding opinions or adding more) and/or the problem of equal intervals between the categories.

\section{Procedure}

After being informed of the purpose and procedure of the study via emails or phone calls, 195 Turkish and 311 Netherlander teachers, from different parts of their countries, agreed to do the survey. Data collection occurred between February and March 2017. The survey was available online. 15-20 minutes were needed to complete all questions.

\section{Focus group interviews}

In April 2018, a 50-minute focus group interview, designed to explore themes emerging from the survey, was conducted with a responsive sample of 10 teachers (five female, five male-6 Turkish and 4 Netherlander) to ensure representativeness of participants. A guide, based on theory and the researcher's experience, was used for the semi-structured interviews (Harrell \& Bradley, 2009). The interviews were conducted by the researchers in teachers' native language, to decrease anxiety levels. It was explained that anonymity would be guaranteed, and that pseudonyms would be used when citing participant comments. In total, three separate focus group interviews were held because of the location of the participants. The first focus group, with three participants, was conducted face to face. The second focus group, with four, was online (Skype) and the third, with three participants, on the phone. Even though the medium the interviews might have created a burden on the participants, the advantages were twofold. First, interviews increased the interrater reliability of the study, and they enabled the researcher to identify teachers' individual beliefs on gender issues especially how these affect their teaching. Second, issues emerging from teachers' reactions were discussed, and this in turn helped develop insights, 
while also presenting an opportunity to explore issue of gender and teaching from a different perspective.

\section{Data Analysis}

Factor analysis was applied for exploring the basic factors of the questionnaire and a t-test (one-way ANOVA) was used. Factor analysis also confirmed that the measurement scales used in the constructs met the standards of validity and reliability. In order to test the items' internal reliability consistency, Cronbach Coefficient Alpha was used. The results indicate coefficient values ranging from 0.84 to 0.91 , representing a good level of reliability (George \& Mallery, 2003: 231). According to the results of Barlett's Sphericity, items with significance value less than 0.05 were left out in order to increase the reliability of the scale.

\section{Results}

The study in hand addresses two main questions: first, what are Turkish teachers' perceptions of gender identity, and secondly, do these perceptions differ from the Netherlander teachers?

\section{a. Results about Turkish Teachers'attitudes}

In terms of gender (the first eight questions) almost $80 \%$ of the Turkish teachers $(79.0 \%)$ strongly deny preference for teaching homogenous classes, and related to this $72.3 \%$ say that they do not teach boys and girls differently. Gender identity results, the second subscale, show that teachers do not agree (33.3\% strongly agree) that people should perceive homosexuality as equal to heterosexuality, but $38.5 \%$ of the teachers believe that gays/lesbians should have the same right as heterosexuals. However, the percentage decreases to $25.6 \%$ concerning rights to marry.

The total of the participants who strongly or slightly disagreed with the statement "It wouldn't be any problem for my parents if I were gay" is $63.6 \%$ $(48.2+15.4)$. More than half of the participants reported that it would not be a problem for them if their best friend come out as gay or lesbian. Moreover, $50.8 \%$ percent of the participants strongly disagree with the statement that 
they would break with their best friend if she/he came out as gay. Adding the percentage of the participants who slightly disagree, a total of $64.1 \%$ would continue their friendship.

Turkish teachers' answers to two questions on the survey seem to present a contradiction. Only $5.1 \%$ of teachers strongly disagree with the statement "Homosexuality is a natural thing.", meaning that for them it is not normal; however, this is contradicted by the answers to the statement "Being gay or lesbian means being ill.", for which the results were $43.1 \%$ strongly disagree, $16.9 \%$ slightly disagree, and only $9.2 \%$ agree.

As for the third subscale, gender identity and teaching, Turkish teachers tend to disagree with the idea of supporting their gay/lesbian students $(12.3 \%$ strongly disagree, $10.8 \%$ slightly disagree, $23.6 \%$ disagree). In total $46.7 \%$ of the participants disagree with the statement "If I realized that one of my students is gay/lesbian I'd support him/her." The total of the teachers who agree is $36.4 \%$. The percentage of the teachers who would inform the school that a student is gay/lesbian is $13.8 \%$, while a similar proportion, $14.9 \%$ would inform parents. When the same teachers were asked about their reactions to a gay/lesbian colleague, they seemed to be more open and supportive. $63.6 \%$ of the teachers strongly disagreed with avoiding contact, while only 0.5 agreed. Ideas vary when teachers were asked about supporting their gay/lesbian colleagues in the presence of other colleagues. $10.3 \%$ strongly disagree, $9.2 \%$ slightly disagree, $7.2 \%$ disagree, $10.8 \%$ agree, $13 \%$ slightly agree, $28.7 \%$ strongly agree. 


\section{TABLE 2. RESULTS OF TURKISH TEACHERS}

\begin{tabular}{|c|c|c|c|c|c|c|c|c|}
\hline & 1 & 2 & 3 & 4 & 5 & 6 & Total & Mean \\
\hline $\begin{array}{l}\text { During my lessons I observe that boys and girls } \\
\text { behave in a different way }\end{array}$ & 17,9 & 7,7 & 21,0 & 14,4 & 14,4 & 13,3 & 88,7 & 3,45 \\
\hline $\begin{array}{l}\text { During my lessons I have a different attitude } \\
\text { towards boys and girls }\end{array}$ & 55,9 & 14,9 & 6,7 & 4,6 & 2,1 & 1,5 & 85,6 & 1,68 \\
\hline $\begin{array}{l}\text { I think that a student outing himself/herself as } \\
\text { homosexual would be problematic at our school }\end{array}$ & 25,1 & 12,8 & 19,5 & 6,2 & 7,7 & 15,9 & 87,2 & 3,07 \\
\hline Our school attaches importance to gender issues & 20,0 & 18,5 & 23,6 & 11,3 & 4,1 & 8,7 & 86,2 & 2,85 \\
\hline I teach boys differently to girls & 72,3 & 7,7 & 3,6 & 1,5 & 1,5 & 0,5 & 87,2 & 1,32 \\
\hline $\begin{array}{l}\text { I would prefer to teach only boys or girls } \\
\text { (homogenous class groups) }\end{array}$ & 79,0 & 1,5 & 2,6 & 0,5 & 2,1 & 1,0 & 86,7 & 1,25 \\
\hline $\begin{array}{l}\text { In daily life outside school I have a different } \\
\text { attitude towards boys and girls }\end{array}$ & 65,1 & 8,7 & 7,2 & 2,6 & 1,0 & 2,1 & 86,7 & 1,52 \\
\hline $\begin{array}{l}\text { A friend outing himself/herself as homosexual } \\
\text { would be problematic for me }\end{array}$ & 55,4 & 10,3 & 8,7 & 4,1 & 3,6 & 4,6 & 86,7 & 1,89 \\
\hline Homosexuality is a natural thing & 5,1 & 7,7 & 16,4 & 11,3 & 18,5 & 28,2 & 87,2 & 5,67 \\
\hline $\begin{array}{l}\text { People should perceive homosexuality as equal } \\
\text { to heterosexuality }\end{array}$ & 5,6 & 5,6 & 16,9 & 9,7 & 16,8 & 33,3 & 85,1 & 4,42 \\
\hline $\begin{array}{l}\text { Gays/lesbians should have the same rights as } \\
\text { heterosexuals }\end{array}$ & 5,1 & 6,7 & 10,8 & 7,7 & 16,9 & 38,5 & 85,6 & 4,63 \\
\hline $\begin{array}{l}\text { Gays/lesbians should have the right to get } \\
\text { married }\end{array}$ & 15,9 & 4,6 & 16,4 & 9,7 & 12,3 & 25,6 & 84,6 & 3,88 \\
\hline $\begin{array}{l}\text { Gays/lesbians should have the right to adopt } \\
\text { children }\end{array}$ & 24,6 & 11,8 & 11,3 & 7,2 & 11,3 & 17,4 & 83,6 & 3,25 \\
\hline $\begin{array}{l}\text { I do not have any problem if } 2 \text { women or } 2 \text { men } \\
\text { hold hands in public }\end{array}$ & 15,4 & 7,7 & 16,4 & 8,7 & 12,3 & 24,6 & 85,1 & 3,81 \\
\hline $\begin{array}{l}\text { I do not have any problem at all if } 2 \text { women or } 2 \\
\text { men are kissing each other public }\end{array}$ & 26,7 & 10,8 & 18,5 & 4,1 & 9,2 & 15,4 & 84,6 & 3,05 \\
\hline $\begin{array}{l}\text { It wouldn't be any problem for me if my best } \\
\text { friend were coming-out as gay or lesbian }\end{array}$ & 12,3 & 10,3 & 7,2 & 10,3 & 10,8 & 33,8 & 84,6 & 4,16 \\
\hline $\begin{array}{l}\text { It wouldn't be any problem for my parents if my } \\
\text { best friend were coming-out as gay or lesbian }\end{array}$ & 25,1 & 15,9 & 8,2 & 14,4 & 6,7 & 14,9 & 85,1 & 3,07 \\
\hline Being gay or lesbian means being ill & 43,1 & 16,9 & 9,2 & 3,6 & 6,2 & 5,6 & 84,6 & 2,17 \\
\hline $\begin{array}{l}\text { It wouldn't be any problem for my parents if I } \\
\text { were gay }\end{array}$ & 48,2 & 15,4 & 13,3 & 4,1 & 2,6 & 2,6 & 86,2 & 1,90 \\
\hline $\begin{array}{l}\text { I would break with my best friend if she/he were } \\
\text { come out as gay }\end{array}$ & 50,8 & 13,3 & 9,7 & 2,1 & 5,6 & 3,6 & 85,1 & 1,93 \\
\hline $\begin{array}{l}\text { I do not have any problem at all if a man and } \\
\text { woman are kissing each other in public }\end{array}$ & 15,4 & 10,3 & 16,4 & 7,7 & 12,3 & 23,6 & 85,6 & 3,72 \\
\hline $\begin{array}{l}\text { I do not have any problem if a man and a woman } \\
\text { hold hands in public }\end{array}$ & 5,1 & 4,6 & 7,2 & 4,1 & 8,7 & 54,4 & 84,1 & 5,02 \\
\hline If I would realize that... & & & & & & & & \\
\hline $\begin{array}{l}\text { one of my students is gay/lesbian I'd support } \\
\mathrm{him} / \mathrm{her}\end{array}$ & 12,3 & 10,8 & 23,6 & 11,8 & 7,7 & 16,9 & 83,1 & 3,51 \\
\hline $\begin{array}{l}\text { one of my students is gay/lesbian I'd inform the } \\
\text { director of the school }\end{array}$ & 35,9 & 11,8 & 7,7 & 4,6 & 6,2 & 13,8 & 80,0 & 2,69 \\
\hline $\begin{array}{l}\text { one of my students is gay/lesbian I'd inform his/ } \\
\text { her parents }\end{array}$ & 27,2 & 9,7 & 13,8 & 9,2 & 7,2 & 14,9 & 82,1 & 3,05 \\
\hline $\begin{array}{l}\text { there is bullying of gay/lesbian students I } \\
\text { wouldn't interfere }\end{array}$ & 67,2 & 6,7 & 2,1 & 2,1 & & 2,1 & 80,0 & 1,37 \\
\hline
\end{tabular}




\begin{tabular}{|c|c|c|c|c|c|c|c|c|}
\hline $\begin{array}{l}\text { there are gay/lesbian students in my class I'd use } \\
\text { different didactical approaches }\end{array}$ & 45,1 & 9,2 & 14,9 & 4,1 & 4,6 & 3,6 & 81,5 & 2,08 \\
\hline $\begin{array}{l}\text { there are gay/lesbian students I'd use different } \\
\text { examples during classes }\end{array}$ & 32,3 & 8,2 & 14,4 & 10,8 & 6,2 & 7,7 & 79,5 & 2,66 \\
\hline $\begin{array}{l}\text { one of my colleagues is gay/lesbian I'd support } \\
\mathrm{him} / \mathrm{her}\end{array}$ & 10,3 & 9,2 & 17,4 & 11,8 & 12,3 & 20,0 & 81,0 & 3,82 \\
\hline $\begin{array}{l}\text { one of my colleagues is gay/lesbian I'd inform } \\
\text { the director of the school }\end{array}$ & 57,9 & 9,7 & 4,6 & 2,1 & 1,0 & 4,1 & 79,5 & 1,63 \\
\hline $\begin{array}{l}\text { one of my colleagues is gay/lesbian I'd inform } \\
\text { my colleagues of the school }\end{array}$ & 56,9 & 11,8 & 7,2 & 2,6 & 1,0 & 1,0 & 80,1 & 1,54 \\
\hline $\begin{array}{l}\text { one of my colleagues is gay/lesbian I'd tell } \\
\text { students }\end{array}$ & 72,3 & 4,6 & 1,5 & & 0,5 & 0,5 & 79,5 & 1,15 \\
\hline $\begin{array}{l}\text { one of my colleagues is gay/lesbian I'd avoid } \\
\text { any contact with him/her }\end{array}$ & 63,6 & 8,7 & 6,2 & 1,0 & 1,0 & 0,5 & 81,0 & 1,38 \\
\hline $\begin{array}{l}\text { one of my colleagues is gay/lesbian I'd try to } \\
\text { convince my colleagues at school that this is not } \\
\text { an issue }\end{array}$ & 10,3 & 9,2 & 7,2 & 10,8 & 13,3 & 28,7 & 79,5 & 4,18 \\
\hline $\begin{array}{l}\text { one of my colleagues is gay/lesbian, it would } \\
\text { make things difficult to handle at school }\end{array}$ & 50,3 & 13,3 & 9,7 & 2,6 & 3,1 & 1,0 & 80,0 & 1,72 \\
\hline $\begin{array}{l}\text { the general atmosphere (e,g, newspapers, law, } \\
\text { public opinion) towards homosexuality is } \\
\text { improving }\end{array}$ & 20,0 & 17,4 & 23,6 & 12,8 & 2,6 & 5,6 & 82,1 & 2,73 \\
\hline $\begin{array}{l}\text { the law on homosexuality has been improving } \\
\text { towards homosexuality during the last } 10 \text { years }\end{array}$ & 26,7 & 16,9 & 23,1 & 7,7 & 5,6 & 1,5 & 81,5 & 2,43 \\
\hline $\begin{array}{l}\text { I am checking how my students are behaving } \\
\text { towards each other on social media (Facebook, } \\
\text { WhatsApp, etc.) }\end{array}$ & 34,9 & 9,7 & 12,8 & 13,8 & 4,6 & 5,1 & 81,0 & 2,49 \\
\hline
\end{tabular}

1. Strongly Disagree 2. Slightly Disagree 3. Disagree 4. Agree 5. Slightly Agree 6. Strongly Agree. Source: Prepared by the author.

\section{b. Results about Netherlander and Turkish teachers' comparisons}

In comparing the perceptions of teachers' attitudes regarding gender, gender identity, and gender identity and teaching, the two national data sets were analysed through a means testing approach. Looking at each item listed under all three subscales, at first glance, it is possible to say that Netherlander and Turkish teachers seem to have similar opinions about gender, gender identity, and gender identity and teaching. When the results are examined item by item, however, there are differences. For example, for the item "During my lessons I observe that boys and girls behave in a different way", the mean of the Netherlander teachers is 4.94 , i.e. approximately 5 (slightly agree), however, Turkish teachers' mean is 3.45 , i.e. disagree. Another difference can be seen in item "People should perceive homosexuality as equal to heterosexuality", the mean for the Netherlander teachers is 5.67 i.e. almost 6 , and for the Turkish teachers' 4.47 . 
TABLE 3. RESULTS OF NETHERLANDER AND TURKISH TEACHERS

\begin{tabular}{|c|c|c|c|c|c|c|}
\hline & My country & $N$ & Mean & $\begin{array}{r}\text { Std. } \\
\text { Deviation }\end{array}$ & $\begin{array}{r}\text { Std. } \\
\text { Error } \\
\text { Mean }\end{array}$ & Sig. \\
\hline \multicolumn{7}{|l|}{ Gender } \\
\hline \multirow{2}{*}{$\begin{array}{l}\text { During my lessons I observe that boys and girls } \\
\text { behave in a different way }\end{array}$} & Netherlands & 282 & 4,94 & 1,13 &, 06 & ,000 \\
\hline & Turkey & 173 & 3,45 & 1,69 &, 12 & \\
\hline \multirow{2}{*}{$\begin{array}{l}\text { During my lessons I have a different attitude } \\
\text { towards boys and girls }\end{array}$} & Netherlands & 282 & 2,54 & 1,31 &, 07 &, 001 \\
\hline & Turkey & 167 & 1,68 & 1,16 & ,09 & \\
\hline \multirow{2}{*}{$\begin{array}{l}\text { I think that a student outing himself/herself as } \\
\text { homosexual would be problematic at our school }\end{array}$} & Netherlands & 282 & 2,71 & 1,31 & 07 &, 000 \\
\hline & Turkey & 170 & 3,07 & 1,83 &, 14 & \\
\hline \multirow{2}{*}{ Our school attaches importance to gender issues } & Netherlands & 273 & 3,63 & 1,45 & 08 &, 817 \\
\hline & Turkey & 168 & 2,85 & 1,53 &, 11 & \\
\hline \multirow{2}{*}{ I teach boys differently to girls } & Netherlands & 282 & 2,63 & 1,42 & 08 &, 000 \\
\hline & Turkey & 170 & 1,32 & ,86 & ,06 & \\
\hline \multirow{6}{*}{$\begin{array}{l}\text { I would prefer to teach only boys or girls } \\
\text { (homogenous class groups) } \\
\text { In daily life outside school I have a different } \\
\text { attitude towards boys and girls } \\
\text { A friend outing himself/herself as homosexual } \\
\text { would be problematic for me }\end{array}$} & Netherlands & 281 & 1,72 & 1,26 &, 07 &, 000 \\
\hline & Turkey & 169 & 1,25 &, 89 & 06 & \\
\hline & Netherlands & 278 & 2,15 & 1,41 & 08 &, 000 \\
\hline & Turkey & 169 & 1,52 & 1,10 & 08 & \\
\hline & Netherlands & 280 & 1,19 & ,70 & 04 &, 000 \\
\hline & Turkey & 169 & 1,89 & 1,46 &, 11 & \\
\hline \multicolumn{7}{|l|}{ Gender Identity } \\
\hline \multirow[t]{2}{*}{ Homosexuality is a natural thing } & Netherlands & 278 & 5,55 & ,94 & 057 &, 000 \\
\hline & Turkey & 170 & 4,32 & 1,57 &, 121 & \\
\hline \multirow{2}{*}{$\begin{array}{l}\text { People should perceive homosexuality as equal to } \\
\text { heterosexuality }\end{array}$} & Netherlands & 277 & 5,67 & ,90 &, 05 &, 000 \\
\hline & Turkey & 166 & 4,42 & 1,62 &, 12 & \\
\hline \multirow[t]{2}{*}{$\begin{array}{l}\text { Gays/lesbians should have the same rights as } \\
\text { heterosexuals }\end{array}$} & Netherlands & 279 & 5,65 & ,92 &, 05 &, 000 \\
\hline & Turkey & 167 & 4,63 & 1,60 &, 12 & \\
\hline \multirow[t]{2}{*}{ Gays/lesbians should have the right to get married } & Netherlands & 278 & 5,68 & ,96 &, 05 &, 000 \\
\hline & Turkey & 165 & 3,88 & 1,86 &, 14 & \\
\hline \multirow[t]{2}{*}{ Gays/lesbians should have the right to adopt children } & Netherlands & 275 & 5,20 & 1,37 &, 08 &, 000 \\
\hline & Turkey & 163 & 3,25 & 1,94 &, 15 & \\
\hline \multirow{2}{*}{$\begin{array}{l}\text { I do not have any problem if } 2 \text { women or } 2 \text { men } \\
\text { hold hands in public }\end{array}$} & Netherlands & 277 & 5,74 &, 84 &, 05 &, 000 \\
\hline & Turkey & 166 & 3,81 & 1,86 &, 14 & \\
\hline \multirow{2}{*}{$\begin{array}{l}\text { I do not have any problem at all if } 2 \text { women or } 2 \\
\text { men are kissing each other public }\end{array}$} & Netherlands & 277 & 5,36 & 1,15 &, 06 &, 000 \\
\hline & Turkey & 165 & 3,05 & 1,87 &, 14 & \\
\hline \multirow[t]{2}{*}{$\begin{array}{l}\text { It wouldn't be any problem for me if my best friend } \\
\text { were coming-out as gay or lesbian }\end{array}$} & Netherlands & 277 & 5,62 & 1,06 & 06 &, 000 \\
\hline & Turkey & 165 & 4,16 & 1,89 &, 14 & \\
\hline \multirow[t]{2}{*}{$\begin{array}{l}\text { It wouldn't be any problem for my parents if my } \\
\text { best friend were coming-out as gay or lesbian }\end{array}$} & Netherlands & 269 & 4,38 & 1,75 &, 10 & ,303 \\
\hline & Turkey & 166 & 3,07 & 1,85 &, 14 & \\
\hline \multirow[t]{2}{*}{ Being gay or lesbian means being ill } & Netherlands & 275 & 1,14 & ,76 &, 04 &, 000 \\
\hline & Turkey & 165 & 2,17 & 1,58 &, 12 & \\
\hline \multirow{2}{*}{$\begin{array}{l}\text { It wouldn't be any problem for my parents if I } \\
\text { were gay }\end{array}$} & Netherlands & 268 & 3,42 & 1,66 &, 10 &, 000 \\
\hline & Turkey & 168 & 1,90 & 1,28 & ,09 & \\
\hline \multirow[t]{2}{*}{$\begin{array}{l}\text { I would break with my best friend if she/he were } \\
\text { come out as gay }\end{array}$} & Netherlands & 277 & 1,13 & ,69 &, 04 &, 000 \\
\hline & Turkey & 166 & 1,93 & 1,44 &, 11 & \\
\hline \multirow[t]{2}{*}{$\begin{array}{l}\text { I do not have any problem at all if a man and } \\
\text { woman are kissing each other in public }\end{array}$} & Netherlands & 274 & 5,45 & 1,10 & ,06 &, 000 \\
\hline & Turkey & 167 & 3,72 & 1,86 & $\left(\begin{array}{l}14 \\
(\text { Cont }\end{array}\right.$ & tinue) \\
\hline
\end{tabular}




\section{(Conclusion)}

I do not have any problem if a man and a woman hold hands in public

\begin{tabular}{lrrrrr} 
Netherlands & 276 & 5,78 &, 79 &, 04 &, 000 \\
Turkey & 164 & 5,02 & 1,58 &, 12 & \\
\hline
\end{tabular}

Gender Identity and Teaching

If I would realize that...

one of my students is gay/lesbian I'd support him/her

one of my students is gay/lesbian I'd inform the

director of the school

one of my students is gay/lesbian I'd inform his/ her parents

there is bullying of gay/lesbian students I wouldn't interfere

there are gay/lesbian students in my class I'd use different didactical approaches

there are gay/lesbian students I'd use different examples during classes

one of my colleagues is gay/lesbian I'd support him/her

one of my colleagues is gay/lesbian I'd inform the director of the school

one of my colleagues is gay/lesbian I'd inform my colleagues of the school

Netherlands $\quad 273 \quad 5,53$

Netherlands

1623,51

,95

$, 05 \quad, 000$

Turkey

27

1,62

1,68

, 13

Netherlands

$156 \quad 2,69$

1,17

,07,000

Turkey

272

1,31

$1,94 \quad, 15$

Netherlands

1603,05

,81 ,000

$273 \quad 1,58$

1,88

Turkey

$156 \quad 1,37$

1,55

$, 09,001$

Netherlands

272

2,07

1,05 ,08

Turkey

$159 \quad 2,08$

1,41

,08 ,420

Netherlands

271

2,24

1,46 ,11

Turkey

155

2,66

1,45

$, 08,002$

Netherlands

$268 \quad 5,41$

1,71

Turkey

158

1,14

$, 07,000$

Netherlands

269

3,82

1,71

Turkey

155

1,03

,24$$
13
$$

Netherlands$$
1,63
$$

$1,30 \quad, 10$

Turkey

$271 \quad 1,08$

,44

,02,000

one of my colleagues is gay/lesbian I'd tell students

one of my colleagues is gay/lesbian I'd avoid any contact with $\mathrm{him} / \mathrm{her}$

$157 \quad 1,54$

1,01

, 08

\section{Turkey}

272

1,06

4

$, 02,001$

Netherlands

155

1,15

,57 ,04

Turkey

1,03

,31

$, 01,000$

one of my colleagues is gay/lesbian I'd try to convince my colleagues at school that this is not an issue

Netherlands $\quad 270 \quad 4,37$

,86 ,069

$1,74 \quad, 10 \quad 283$

one of my colleagues is gay/lesbian, it would make things difficult to handle at school

Turkey

1554,18

$1,82 \quad, 14$

Netherlands

$273 \quad 1,28$

, 81

$, 04,000$

the general atmosphere (e.g. newspapers, law, public opinion) towards homosexuality is improving

Turkey

$156 \quad 1,72$

1,16 09

Netherlands

$272 \quad 4,21$

1,07 ,06 ,000

Turkey

$160 \quad 2,73$

$1,42 \quad, 11$

the law on homosexuality has been improving towards homosexuality during the last 10 years

Netherlands

$270 \quad 4,62$

1,03 ,06 ,000

I am checking how my students are behaving towards each other on social media (Facebook, WhatsApp...)

SOURCE: Prepared by the author. 
The two groups disagreed on some items, one of which is "gays/lesbians should have the right to get married". The means are 5.68 to 3.88 for the Netherlander and Turkish teachers respectively. Teachers also seem to disagree on the item "if one of my colleagues is gay/lesbian, I'd support him/her" with similarly different mean scores, 5.41 and 3.82 respectively.

Netherlander teachers seem to be more positive about the general atmosphere towards homosexuality in their country, 4.21 ; whereas, Turkish teachers' mean score is 2.73 , implying that in newspapers, there is no improvement in the general atmosphere towards homosexuality. The same applies to the next item, which asks about opinions on the improvements on the law on homosexuality during the last 10 years. Again, the Netherlander teachers' higher mean score indicates that, the law has developed in the Netherlands, but not in Turkey.

According to the results of the Independent Samples Test, the first item 'During my lessons, I observe that boys and girls behave in a different way' is one of the many items which Netherlander and Turkish teachers' attitudes differ significantly in terms of significance value at $p=0.05$. The results indicated that $(p=0.00<0.05)$ among eight items, there are statistically significant difference in seven responses (item 1). During my lessons, I observe that boys and girls behave in a different way $(p<.01) .2$. During my lessons, I have a different attitude towards boys and girls $(p<.00)$. 3. I think that a student outing himself/ herself as homosexual would be problematic at our school $(p<.02)$. 5. I teach boys differently to girls $(p<.00)$. 7. In daily life (outside school), I have a different attitude towards boys and girls $(p<.01)$. The only item for which there is no statistical significance between the two groups of teachers is "Our school attaches importance to gender issues" $(p>.08)$.

The second subscale shows a similar pattern. Among 14 items, only one item, "It wouldn't be any problem for my parents if my best friend come-out as gay or lesbian", is not statistically significant between the two groups $(\mathrm{p}>$ $.08)$. In the third subscale, the differences in two participant groups' opinions are statistically significant for all items except "If I realized that there are gay/ lesbian students in my class, I'd use different didactical approaches" $(\mathrm{p}>.42)$.

\section{Discussion}

Because they have the power to improve the school conditions, but more importantly, because they are humans who touch children's lives, teachers should be prepared to support students of different sexual orientation, gender identity, 
gender expression, and other identities, such as race, religion, and disability. Different forms of training - preservice teacher education and in-service professional development - can help teachers overcome such prejudices and biases. Education programs and/or Faculty of Education curriculum in particular should include attention to the topics discussed so far.

Gender, gender identity and other subtopics are not only taboos in schools, but in the family as well. Vela $\left(2012, \S 1^{\circ}\right)$ says "As Turks debate the pros and cons of more traditional versus more liberal social values, one subject remains off the table - sexuality and sex education". In an environment where the concept is a taboo, how else can we expect teachers to behave? One teacher, Ali (32), states that the Islamist rooted, conservative party leading the Turkish government "may think [that] if you talk about sexuality and sex a lot, maybe these kids will become too curious about it". A newly graduated 24 years old teacher reflects this view, "There is a fear in society that the established values will be challenged by talking about or teaching sex".

One of the reasons why Turkish teachers are less reluctant to support their gay/lesbian students, might be the lack of openness engendered by the educational system itself. According to the OECD report (2018) the capacity of teachers to respond to school needs can be limited by weak initial education and training and teachers' lack of experience, as well as by the lack of flexibility accorded to schools within the governance structure. For example, one Turkish teacher Nurhan (46), stated her concerns about "the hidden pressure" they feel from the ministry, which sometimes causes her to hesitate before she reacts. She says, "I am not free as a teacher, I have my principal, the principal has the district national education director, he has the provincial national education director, and it goes on. Nobody in the system is free". This might be the reason why Turkish teachers prefer to report the presence of gay/lesbian student in their class to their directors, as a way of passing on the responsibility. On the other side, no Netherlander participants mentioned any kind of administrative pressure, which shows more flexibility given to the schools within the governance system.

To me, the most striking difference between the two groups emerged with the question "How do you react when you find out that a student in your class is bullied because s/he is homosexual?". Ronald (32), one of the Netherlander teachers, underlines the importance of value training, and warns that ignoring the problem will make it worse. "I can never disregard the importance of the situation. Dialog has always been my best solution. I would talk to the kids bullying their friends and even create a classroom discussion, and make some kind of mediation". The Turkish counterpart, Serkan (43) on the other hand, openly states that "This is not my job, I am not a counselor. So I would not talk 
to the kids but send them to the school counselor. I may say wrong things, and damage the children's psychology."

In a study conducted by Kuprienko (2015), the aim was to find the levels of student teachers' general cognitive and psychological aptitude regarding support for people with stigmatized gender identity and sexual orientation. It was found that 85 percent of surveyed students at teacher colleges were psychologically unprepared to effectively provide psychological pedagogical support, while as many as 40 percent had negative and destructive attitudes toward homosexuals. Similarities are seen in Turkey, where most teachers state that they would not know what to do if a student come out. Güzin (50) says that "I would not even know how to react to him/her. Am I gonna say OK, or "geçmiş olsun!" (in Turkish "I wish you a recovery").

Talking about sexuality education, Collier-Harris and Goldman (2017) very optimistically declared that in almost every country, documents detailing effective educational and structural guidance, content, pedagogies, and student-learning standards have been developed for adaptation and implementation by teachers, and national curricula. However, this seems unrealistic in the case of Turkey, which, compared to most other countries, is far behind expectations. As can be seen from the results, Turkish teachers need much more support and education to reach a future in which all school students have the opportunity to learn and succeed, regardless of sexual orientation, gender identity, or gender expression.

One of the roles of a teacher and/or school administration is to ensure a safe environment for all students, which implies all children embracing respect and tolerance for all, regardless of sexual orientation or gender identity/expression. In order to develop school climates where difference is valued, information on sexual diversity should be included in the secondary, high school curriculums, and preservice teachers should be trained in homophobia awareness and sexual diversity issues.

\section{Conclusion}

By comparing teachers from two different cultural perspectives, 506 teachers' understanding of gender identity and how this perspective difference is reflected in their daily practices. On the basis of this evidence, it argues that, teachers have a vital role in changing the culture of schools regarding support for 'the other' students. One could easily assume that the differences in perception is a reflection of the cultures in which teachers were born, raised and are a part 
of. Netherlander teachers were more tolerant, understanding, and developed stronger empathy with their students, whereas Turkish teachers seemed to be more hesitant about the topic, for reasons addressed above. Even though most of the Turkish teachers expressed their personal interest and support on the issue, they are constrained by institutional and cultural factors.

It is clear that, in Turkey there is a need for action to create schools which are less controlling and more open for expression for both teachers and students. Supportive staff can change the school climate for all students. Furthermore, results suggest that how comprehensive anti-bullying/harassment laws can positively affect the school climate for these students.

There is thus an urgent need, especially in Turkey, for more research that explores how teachers can learn to become a guide to 'the other', and the extent to which this increases the student motivation and success. Teachers in Turkey are not deliberately obstructive, but they lack the knowledge to perform this role of guiding students with a different sexual preference. The first step is providing training for school staff to improve rates of intervention and increasing the number of supportive teachers, and other staff available can be the first resulting in a healthier and happier community. It is important to find ways to train teachers with the skills and attitudes that will create more vibrant and diverse schools.

\section{REFERENCES}

Collier-Harris, Christine. A. \& Goldman, Juliette. D. G. (2017). Could Australia have its own teacher professional standards for teaching relationships and sexuality education? Sex Education, 17(5), 512-528.

Ferfolja, Tania. (2007). Schooling cultures: Institutionalizing heteronormativity and heterosexism. International Journal of Inclusive Education, 11(2), 147-162.

Gorski, Paul C., Shannon, N. Davis. \& Reiter, Abigail. (2013). An examination of the (In)visibility of sexual orientation, heterosexism, homophobia, and LGBTQ concerns in U.S. Multicultural teacher education coursework. Journal of LGBT Youth, 10(3), 224-248.

Harrell, Margaret C., \& Bradley, Melissa A. (2009). Data collection methods: semistructured interviews and focus groups. National Defense Research Institute, Santa Monica, CA: RAND.

Kaldi, Stavroula, Govaris, Christos \& Filippatou, Diamanto. (2018). Teachers' views about pupil diversity in the primary school classroom. Compare: A Journal of Comparative and International Education, 48(1), 2-20. 
Kosciw, Joseph G., Greytak, Emily A., Bartkiewicz, M. J., Boesen, Madelyn J., \& Palmer, Neal A. (2012). The 2011 National School Climate Survey: The experiences of lesbian, gay, bisexual and transgender youth in our nation's schools. New York: GLSEN.

Kosciw, Joseph G., Greytak, Emily A., Palmer, Neal A., \& Boesen, Madelyn J. (2014). The 2013 National School Climate Survey: The experiences of lesbian, gay, bisexual and transgender youth in our nation's schools. New York: GLSEN. Retrieved from: https://www.glsen.org/sites/default/files/2013\%20National\%20School\%20Climate $\% 20$ Survey\%20Full\%20Report_0.pdf. Access: 12 dec. 2018.

Kuprienko, Tatyana P. (2015). Cognitive readiness of students at teacher colleges to support individuals with stigmatized gender identity and sexual orientation. Russian Education \& Society, 57(12), 1066-1069.

Müller, Alexandra. (2015). Strategies to include sexual orientation and gender identity in health professions education. American Journal of Health-System Pharmacy,7(1), 4-7.

OECD. Education at a Glance. (2018). OECD Indicators, OECD Publishing, Paris. Retrieved from: www.oecd.org/edu/eag.htm. Access: 12 dec. 2018.

Richard, Gabrielle. (2015). The Pedagogical Practices of Quebec High School Teachers Relative to Sexual Diversity. Journal of LGBT Youth, 12(2), 113-143.

Vela, Justin. (2012). Turkey: Sex Education Remains Taboo Topic. Retrieved from: https://eurasianet.org/s/turkey-sex-education-remains-taboo-topic. Access: 12 dec. 2018.

Text received on December 26, 2018.

Text approved on May 22, 2019. 